\title{
Perancangan Program Aplikasi Penerimaan Mahasiswa Setara Diploma Satu Komputer dengan Bahasa Pemrograman Visual FoxPro ( Lembaga Pendidikan Widya Yahya Computer Gedong Tataan Lampung Selatan)
}

\author{
Marzuki \\ Program Studi Teknik Informatika \\ Fakultas Ilmu Komputer \\ Universitas Bandar Lampung \\ Jln. Z.A. Pagar Alam No.26 Labuhan Ratu Bandar Lampung 35142 \\ Telp. (0721) 701463, (0721) 701979 Fax. (0721) 701467 Web.
}

\begin{abstract}
Abstrak
Seiring dengan kemajuan zaman saat ini, sistem informasi yang menggunakan komputerisasi tidak hanya terbatas pada sistem keuangan tapi juga pada seluruh aspek kehidupan. Saat ini kita dituntut untuk berkerja semakin cepat dan efisien. Maka tidak heran bila terjadi revolusi teknologi dan revolusi informasi, mulai dari internet, server yang memiliki kapasitas yang tinggi dan semakin canggih, memori dengan harga yang murah, dan masih banyak lagi yang pasti membuat kita berfikir bagaimana memanfaatkan semuanya itu. Hal diatas sangat berpengaruh pada pertumbuhan ekonomi dan strategi instansi untuk meningkatkan pelayanan kepada masyarakat. Banyak aspek yang tercakup dalam hal penerimaan yang harus diperhatikan, mulai dari saat mahasiswa diterima, Hal ini yang menjadikan alasan mengapa diperlukan suatu sistem penerimaan mahasiswa yang baik, yang dapat menunjang sistem-sistem yang lain ada pada Lembaga Pendididikan Widya Yahya Computer Tersebut di lampung Selatan.

Untuk mendukung hal tersebut, Lembaga Pendididika Widya Yahya Computer di Lampung Selatan. memiliki sistem informasi penerimaan menggunakan bahasa pemrograman sistem operasi manual atau pembukuan, untuk itulah maka Peneliti ingin melakukan migrasi sistem operasi dari Manual ke Sistem Komputerisasi dengan menggunakan Visual FoxPro karena Visual FoxPro. lebih mudah dioperasikan dan efisien.
\end{abstract}

Kata kunci: Perancangan Program Aplikasi Penerimaan Mahasiswa Setara Diploma Satu

\section{PENDAHULUAN}

Perkembangan teknologi yang semakin canggih di era globalisasi sekarang ini sangat membantu disegala bidang maupun bisnis. Salah satu pertemuan yang bermanfaat dalam bidang teknologi yaitu Komputer.dengan adanya kemajuan teknologi yang sangat canggih ini diharapkan dapat membantu manusia dalam mempermudah pekerjaan-pekerjaannya. Komputer sangat membantu kelancaran dan kemudahan dalam mengerjakan tugas atau pekerjaan dan tepat mencapai hasil yang akurat, cepat, dan rapi.
Seiring dengan kemajuan zaman saat ini, sistem informasi yang menggunakan komputerisasi tidak hanya terbatas pada sistem keuangan tapi juga pada seluruh aspek kehidupan. Saat ini kita dituntut untuk berkerja semakin cepat dan efisien. Maka tidak heran bila terjadi revolusi teknologi dan revolusi informasi, mulai dari internet, server yang memiliki kapasitas yang tinggi dan semakin canggih, memori dengan harga yang murah, dan masih banyak lagi yang pasti membuat kita berfikir bagaimana memanfaatkan semuanya itu. Hal diatas sangat berpengaruh pada pertumbuhan 
ekonomi dan strategi instansi untuk meningkatkan pelayanan kepada masyarakat.

Pada saat ini di indonesia sedang menghadapi krisis di berbagai bidang kehidupan bernegara, dimana salah satunya adalah bidang ekonomi di Indonesia mengalami kesulitan ekonomi untuk melaksanakan pembanguan nasional lapangan kerja semakin berkurang,angka pengangguran semakin bertambah ,pendapatan perkapita nasional semakin menurun banyak perusahaan yang menjadi instrument utama yang menentukan kemakmuran ekonomi suatu bangsa banyak yang tidak dapat melanjutkan usahanya karena kurangnya modal untuk berproduksi.

Banyak aspek yang tercakup dalam hal penerimaan yang harus diperhatikan, mulai dari saat mahasiswa diterima, Hal ini yang menjadikan alasan mengapa diperlukan suatu sistem penerimaan mahasiswa yang baik, yang dapat menunjang sistem-sistem yang lain ada pada Lembaga Pendididikan Widya Yahya Computer Tersebut di lampung Selatan. Untuk mendukung hal tersebut, Lembaga Pendididika Widya Yahya Computer di Lampung Selatan. memiliki sistem informasi penerimaan menggunakan bahasa pemrograman sistem operasi manual atau pembukuan, untuk itulah maka Peneliti ingin melakukan migrasi sistem operasi dari Manual ke Sistem Komputerisasi dengan menggunakan Visual FoxPro karena Visual FoxPro. lebih mudah dioperasikan dan efisien.

\subsection{Identifikasi dan Perumusan Masalah}

Setelah Peneliti melakukan pengamatan pada sistem saat ini, dengan menganalisis aliran prosedurnya, maka dapat dilihat bahwa basis data yang lama masih menimbulkan berbagai kendala, seperti :

a. Kesulitan dalam pekerjaannya, karena sistem operasinya masih menggunakan manual atau pembukuan.

b. Tampilan sistem yang manual atau melalui pembukuan cenderung membuat kejenuhan dalam mengerjakannya.

\subsection{Tujuan dan Manfaat \\ 1.3.1 Tujuan}

a. Peneliti ingin memperkenalkan suatu sistem penerimaan dengan menggunakan bahasa pemrograman Visual FoxPro di lembaga pendidikan Widya Yahya B.Be.C Computer di Gedong Tataan Lampung Selatan.

\subsubsection{Manfaat.}

a. Peneliti ingin memberikan suatu tampilan system penerimaan mahasiswa yang baik.

b. Peneliti ingin lebih memperkenalkan Bahasa Pemrograman Visual FroxPro di Lembaga Pendidikan Widya Yahya Computer Gedung Tataan Lampung Selatan.

c. Dapat merasakan suatu sistem yang baru yang praktis dan mudah dalam pengoperasiannya pada Lembaga Pendidikan Widya Yahya Computer Gedong Tataan Lampung Selatan.

\section{LANDASAN TEORI}

\subsection{Definisi Perancangan}

Perancangan adalah proses, cara, perbuatan merancang. (Tim Penyusun Kamus Besar Bahasa Indonesia Depdikbud, $1990 ; 725$ )

\subsection{Definisi Aplikasi}

Aplikasi adalah satu penerapan. Dalam hal ini aplikasi adalah program yang sudah jadi dan sudah dapat digunakan atau diterapkan oleh pengguna (Suhatman Syah, $1995: 191$ )

\subsection{Konsep Dasar Sistem}

\subsubsection{Definisi Sistem}

Menurut McLeod, Sistem didefinisikan sebagai sekelompok elemen - elemen yang berinteraksi dengan maksud yang sama dan dengan fungsi umum untuk mencapai suatu tujuan (Raymond McLeod : jilid 2 : edisi ketujuh : 304 )

Sistem adalah Suatu kerangka yang terdiri dari berbagai bagian-bagian yang saling terintegrasi dengan maksud untuk mencapai suatu tujuan tertentu,bagian-bagian ini disebut dengan subsistem atau pula yang menyebutnya sebagai prosudur ( Nugroho Widjajanto,1990 : 5-6 ).

Sistem sebagai kumpulan dari elemen-elemen yang saling berinteraksi untuk mencapai tujuan tertentu. ( Senn,1990:25).

Mendefinisikan sistem sebagai sekelompok elemen-elemen yang diintergrasikan dengan fungsi umum untuk mencapai tujuan

( Raymond Mc Lcod 1993 : 19). 
Sistem mempunyai elemen-elemen dasar yang sama yaitu input, output, transformasi, mekanisme pengendalian, dan tujuan.

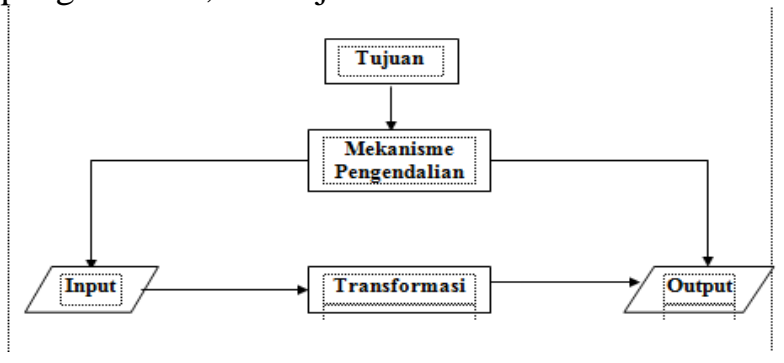

Gambar 2.1 Elemen - elemen dasar sistem.

\subsection{Konsep Dasar Informasi}

\subsubsection{Definisi Informasi}

Informasi merupakan hal yang penting bagi manajemen di dalam pengambilan keputusan. Untuk mendapatkan sebuah informasi biasa diperoleh dari sistem informasi ( information systems ) atau disebut juga dengan processing system information. Informasi didefinisikan sebagai data yang diolah menjadi bentuk yang lebih berguna dan lebih berarti bagi yang memerimanya.

Sistem informasi adalah suatu sistem di dalam suatu organisasi yang mempertemukan kebutuhan pengolahan transaksi harian, mendukung operasi, bersifat manajerial, dan kegiatan strategi dari suatu organisasi dan menyediakan pihak luar tertentu dengan laporan-laporan yang diperlukan ( Robert N.Anthony \& John Dearden,1979 :13-14 ).

\subsubsection{Kualitas Informasi}

Kualitas informasi tergantung pada tiga hal, yaitu a. Akurat

Informasi harus bebas dari kesalahan kesalahan dan harus jelas mencerminkan maksudnya.

\section{b. Tepat Waktu}

Informasi yang datang pada penerima tidak boleh terlambat. Informasi yang sudah usang tidak akan mempunyai nilai lagi. Karena informasi merupakan landasan didalam mengambil keputusan. Bila penga,bilan keputusan terlambat, maka berakibat fatal bagi organisasi.

\section{c. Relevan}

Informasi tersebut mempunyai manfaat bagi pemakainya. Relevansi informasi untuk tiap - tiap orang antara yang satu dengan yang lainnya berbeda - beda.

\subsubsection{Siklus Informasi}

Data merupakan bentuk yang masih mentah yang belum dapat bercerita banyak, sehingga perlu di olah lebih lanjut. Data yang diolah untuk menghasilkan informasi menggunakan suatu model proses yang tertentu. Data yang telah diolah melalui sutu model menjadi informasi., penerima kemudian menerima informasi, membuat suatu keputusan, dan melakukan tindakkan, yang berarti menghasilkan suatu tindakan yang lain yang akan membuat sejumlah data kembali. Data tersebut akan ditangkap sebagai input, di proses kembali lewat suatu model dan seterusnya membentuk sebuah siklus. Siklus ini di sebut dengan siklus informasi ( Information cycle ), tetapi kadang juga disebut sebagai siklus pengolahan data ( Data Processing Cycles ). ( Raymond McLeod : jilid 2 : edisi ketejuh : 307 )

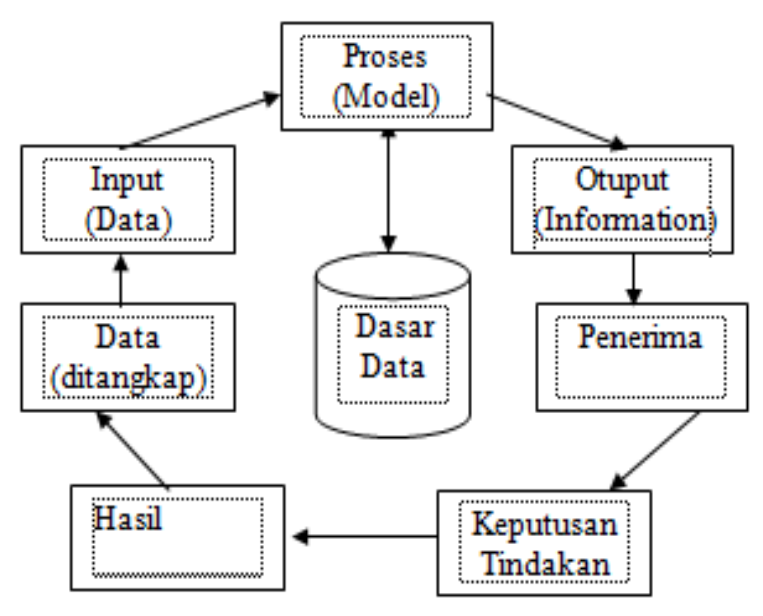

Gambar 2.2 Siklus informasi

\subsection{Definisi Sistem Informasi}

Sistem Informasi adalah suatu sistem di dalam suatu organisasi yang mempertemukan kebutuhan pengolahan transaksi harian, mndukung operasi, bersifat manajerial, dan kegiatan strategi dari suatu organisasi dan menyediakan pihak luar tertentu dengan laporan - laporan yang diperlukan. Sistem Informasi di definisikan oleh ( Leitch, A.R, dan K.R Davis ).

\subsection{Basis Data}


Basis data adalah kumpulan data yang saling berhubungan yang disimpan secara bersama sama sedemikian rupa dan tanpa pengulangan ( redudansi ) yang tidak perlu untuk memenuhi berbagai kebutuhan. Prinsip utama database adalah pengaturan data. Tujuan utama basis data adalah kemudahan dan kecepatan dalam pengambilan kembali data. Basis data terdiri dari dua kata, yaitu basis dan data. Basis dapat diartikan sebagai tempat, sedangkan data adalah representasi fakta dunia nyata yang mewakili suatu objek seperti manusia. Basis data sendiri dapat didefinisikan sebagai berikut :

a. Himpunan kelompok data ( arsip ) yang saling berhubungan yang diorganisasi sedemikian rupa sehingga dapat dimanfaatkan kembali dengan cepat dan mudah.

b. Kumpulan file atau tabel atau arsip yang saling berhubungan yang disimpan dalam media penyimpanan elektronik.(Fathansyah, Ir : $2004: 2$ )

\subsection{ERD ( Entity Relationship Diagram )}

ERD merupakan salah satu bentuk pendekatan model database atau struktur data selain pendekatan hirarki, dan jaringan ( network ). Istilah relational menunjukkan adanya hubungan antara elemen-elemen data baik antara suatu file atau dalam satu file. Entiti diagram juga merupakan model data yang berkaitan erat dengan model relational. Pada model ini mempunyai 3 komponen dasar yaitu entitas, hubungan dan keterkaitan. ERD menggunakan tiga elemen ini dan memungkinkan sistem analis untuk mengambil atribut dari entiti dan mendefinisikan hubungan antara entiti, sehingga menghasilkan model database yang sederhana dan mudah untuk dipahami atau skema sistem. ERD berfungsi untuk menggambarkan relasi dari dua file atau dua tabel. ERD ( Entity Relationship Diagram ), atau diagram Hubungan Entitas didefinisikan sebagai suatu model jaringan yang memakai susunan data yang disimpan dalam sistem secara abstrak. ( Fathansyah, Ir. : 2004 : 79)

\subsubsection{Komponen ERD}

\section{a. Entitas}

Entitas merupakan individu yang mewakili sesuatu yang nyata ( eksistensinya) dan dapat dibedakan dari sesuatu yang lain. Adalah suatu hal ( objek, orang, peristiwa, proses atau konsep ) yang telah didefinisikan data dan entiti merupakan elemen data. Tiap entiti harus mempunyai atribut.

Jenis entitas ( entity type), dapat berupa :

1. Suatu elemen lingkungan,

2. Sumber daya,

3. Transaksi, yang berupa pentingnya bagi perusahaan sehingga didokumentasikan dengan data.

Contoh Entitas adalah semua pelanggan atau pelanggan saja, semua mahasiswa atau mhasiswa saja.. Jenis entitas didokumentasikan dalam ERD dengan segiempat. Tiap segiempat diberi label nama dari jenis entitas - biasanya kata benda tunggal.(Fathansyah, Ir : $2004:$ 73)

\section{b. Hubungan}

Hubungan adalah suatu asosiasi atau kaitan antara dua entitas. Hubungan digambarkan dengan bentuk belah ketupat. Tiap belah ketupat diberi label kata kerja. Contohnya : seorang mahasiswa mengisi faktur penerimaan mahasiswa diisi oleh mahasiswa.

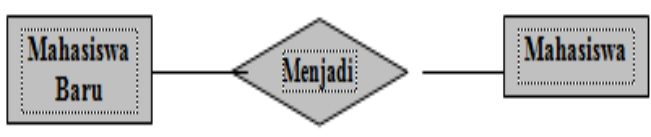

Gambar 2.9 Contoh Hubungan

\section{c.Keterkaitan}

Banyaknya suatu entitas berhubungan dengan entitas lain disebut keterkaitan ( connectivity). Ada 3 jenis keterkaitan, yaitu : satu - ke-satu, satu-ke-banyak, banyak-ke-banyak. Suatu cara umum untuk menunjukkan keterkaitan adalah dengan menggunakan karakter 1 dan $\mathrm{M}$ 


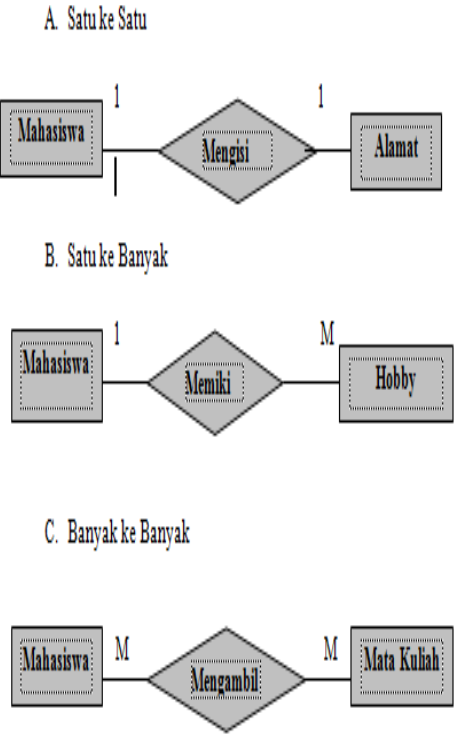

Gambar 2.10 Contoh Jenis-jenis Keterkaitan

\subsection{Pengertian Microsoft Visual Fox Pro}

Microsoft visual Fox Pro atau sering disingkat dengan Fox Pro merupakan suatu bahasa pemrograman visual yang berorientasi pada database. Menggunakan fox pro, pembuatan program aplikasi database akan terasa mudah dan cepat. Microsoft visual fox pro sebenarnya bukanlah pendatang baru dalam dunia pemrograman database. (Kasmoni : $2004: 2$ )

\subsubsection{Komponen - Komponen Microsoft Visual FoxPro}

Berikut ini penjelasan singkat tentang komponen yang ada pada Microsoft visual fox pro .

\subsubsection{Komponen Tampilan Layar}

\section{- $\quad$ MENU BAR}

Ada beberapa menu yang juga dimiliki oleh berbagai aplikasi windows lainnya. Dalam menu bar tersebut terdapat beberapa pilihan utama, yaitu

1. File

Dapat anda gunakan untuk membuat, membuka, menutup, menyimpan dan mencetak file. Di dalamnya juga terdapat menu exit yang berguna untuk keluar dari Microsoft Visual FoxPro.

2. Edit
Berfungsi untuk mengedit. Di dalamnya terdapat pilihan cut, copy, paste dan lainnya.

3. View

Memiliki pilihan toolbar yang dapat anda gunakan untuk mengatur toolbar yang akan anda munculkan di layar.

4. Tool

Dapat anda gunakan untuk mengatur beberapa utility yang ada pada Microsoft Visual FoxPro.

5. Project

Dapat anda gunakan untuk mengelola project yang sedang anda buka.

6. Program

Dapat anda gunakan untuk menjalankan dan menghentikan program serta untuk meng-compile program.

7. Window

Dapat anda gunakan untuk mengelola window window yang dibuka.

8. Help

Dapata anda gunakan untuk membuka system bantuan yang disediakan

9. Tabel

Akan ditambahkan saat anda bekerja dengan data.

10. TOOLBAR

TollBar merupakan sekumpulan tombol yang dapat anda gunakan untuk melakukan berbagai operasi pengelolaan dan pengaturan.

\section{WINDOW VIEW}

Window ini digunakan untuk membuka, mengatur, dan menampilkan data yang ada pada tabel secara tepat.

\section{WINDOW COMMAND}

Jendela command berfungsi sebagai tempat memberikan perintah secara langsung kepada Microsoft Visual FoxPro atau dapat pula diartikan sebagai alternatif dalam memberikan perintah selain menggunakan menubar atau toolbar.

\subsubsection{Komponen Dalam Microsoft Visual FoxPro}

Beberapa komponen dasar yang ada, adalah:

1. Project

Merupakan sebuah file yang memasukan semua file program, form, menu, library, reports, 
label, querie, dan tipe lainnya yang digunakan untuk membuat sebuah aplikasi.

\section{Form}

Merupakan Class Container yang merupakan sekumpulan atau beberapa page seperti window standar atau kotak dialog.

3. Report

Merupakan bentuk desain cetakan informasi data yang akan digunakan sebagai penyaji informasi.

\section{Query}

Merupakan sebuah pendefenisian sebuah informasi dari data base, yang pembentukannya menggunakan criteria untuk mengekstrak record khusus.

5. View

Dapat digunakan sebagai pengasumsian table sementara.

6. Class Library

Class yang didefinisikan secara visual dimasukan dalam sebuah class library.

7. Menu

Merupakan daftar item.

8. Program

Merupakan sebuah file yang berisi satu atau beberapa intruksi atau perintah tersusun secara terstruktur.

\subsubsection{Komponen Data Microsoft Visual FoxPro}

Berikut ini beberapa komponen Data Microsoft Visual FoxPro :

1. Database

Dapat terdiri dari beberapa table.

2. Table

Pada Microsoft Visual FoxPro dapat berisi sampai tiga file yang terintregrasi.

3. Record

Merupakan sebuah unit masukan dalam sebuah tabel.

4. Field

Dalam Microsoft Visual FoxPro nama field sampai 225. Setiap field memiliki satu tipe field dari 13 tipe yang ada.

\section{File.MEM}

Data dapat dimasukan kedalam file.MEM. Data yang dimasukan kedalam file ini biasanya bertipe memo.

\section{METODOLOGI PENELITIAN}

Dalam penyususunan Penelitian ilmiah ini, Penelitian mengadakan persiapan yang terdiri atas beberapa tahap di mulai dari pengumpulan data sampai menganalisis data yang diperoleh sampai dengan mempelajari masalah yang ada.

\subsection{Metode Penelitian}

Metode Penelitian yang di gunakan yang di ambil dari buku Metodologi Penelitian penerbit Gunadarma.Metode penelitian yang di gunakan dalam penelitian ini di tinjau dari sudut pandang yang berhubungan dengan objek yang di teliti adalah eksplanatoris research. Karena penelitian ini di lakukan dengan cara menjelaskan gejala yang di timbulkan oleh satu objek penelitian.peneliti akan berusaha mencari jawaban terhadap penomena suatu permasalah yang timbul.

\subsection{Metode Pengumpulan Data}

Metode yang Peneliti gunakan dalam penyusunan Peneliti ilmiah adalah dengan mengadakan wawancara dan mengamati langsung, yang Peneliti presentasikan dalam bagan alir perosedur system Penerimaan dan bagian-bagian yang terkait dengan sistem penerimaan. Selanjutnya data yang di peroleh kemudian di analisa.

\subsection{Teknik Pengumpulan Data}

\subsubsection{Kepustakaan}

Merupakan penelitian yang di lakukan dengan cara mempelajari sumber-sumber tertulis, seperti buku-buku, dan bahan-bahan tertulis lainnya yang berhubungan dengan pengetahuan teoritis mengenai masalah yang di teliti, dibaca, dicatat, dipelajari seta diresume untuk kemudian di jadikan data. 


\subsubsection{Lapanagan}

a. Observasi

Suatu cara pengumpulan data dengan cara mengadakan pengamatan data langsung pada objek penelitian guna memperolah gambaran yang lebih jelas mengenai sistem penerimaan mahasiswa setara diploma satu komputer pada lembaga pendidikan "Widya Yahya"B.Be.C Computer di Gedong Tataan Lampung Selatan.

b. Interview

Pengumpulan data melalui wawancara secara langsung tethadap orang-orang yang berhubungan langsung dengan penelitian Peneliti hingga mempermudah untuk pengumpulan data

c. Dokumentasi

Yaitu pencatatan terhadap data-data intern yang di butuhkan oleh objek Peneliti yang sesuai dengan system yang akan di analisis

\section{d. Analisa Data}

Data yang di peroleh, kemudian di analisa dan diolah dengan menggunakan bantuan Data Flow Diagram yang terdiri dari Context Diagram, Data Flow Diagram Zero, Data Flow Diagram Detail. Selain itu juga prosedur system yang lama di analisa dan di pelajari untuk kemudian di buat prosedur system yang baru atau prosedur system yang di usulkan

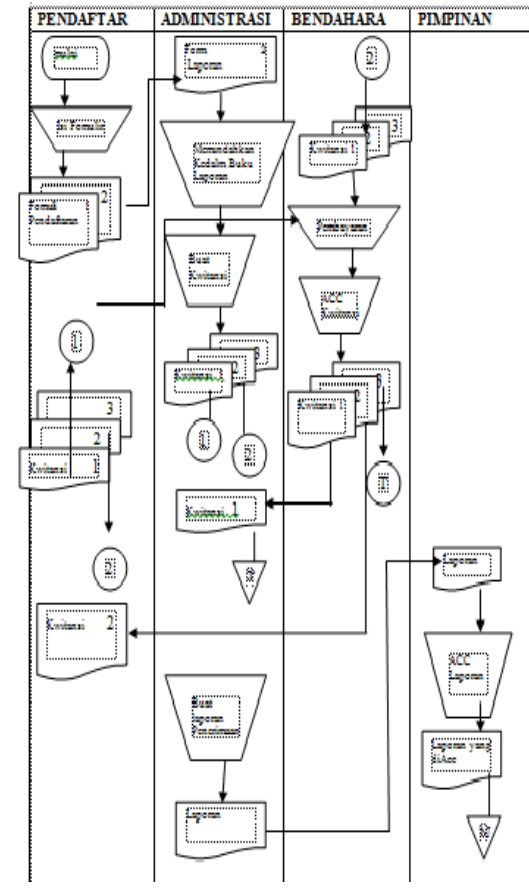

Gambar 3.1 Diagram arus Dokumen Penerimaan Mahasiswa Baru

\subsection{Kelemahan Sistem Penerimaan Mahasiswa Baru Yang Sedang Berjalan}

- Peneliti ingin memperbaiki dan membuat sistem penerimaan mahasiswa yang rapi, tepat sehingga efisien mungkin, kelemahan dalam pembukuan penerimaan mahasiswa baru yang dahulu bisa membuat kehilangan data mahasiswa bila terjadi kelalaian penyimpanan dan kurang rapi dalam pengerjaan Setelah Peneliti melakukan pengamatan pada sistem saat ini, dengan menganalisis aliran prosedurnya, maka dapat dilihat bahwa basis data yang lama masih menimbulkan berbagai kendala atau kekurangan dalam pengoperasian, seperti:

1 Kesulitan dalam pekerjaannya, karena sistem operasinya masih menggunakan manual atau pembukuan.

2 Tampilan sistem yang manual atau melalui pembukuan cenderung membuat kejenuhan dalam mengerjakannya.

Setelah melihat kendala-kendala tersebut Peneliti yaitu dengan membuat basis data sebatas "Perancangan Program Aplikasi Penerimaan Mahasiswa Baru Setara Diploma Satu Komputer dengan Bahasa Pemrograman Visual FoxPro pada 
Lembaga Pendidikan Widya Yahya Computer Gedong Tataan Lampung Selatan, yaitu membuat sistem penerimaan yang lebih mudah dioperasikan, dengan tampilan yang baru tanpa menghilangkan yang ada pada sistem operasi yang lama yaitu mencatat data mahasiswa dan membuat laporan mengenai keseluruhan dari pencatatan data mahasiswa tersebut yang tepat dan efisien sehingga tidak terjadi kesalahan."

\section{HASIL DAN PEMBAHASAN}

\subsection{Context Diagram}

Pada gambar context diagram 4.1 dapat dilihat bahwa terminator penerimaan yang pertama kali datang ke B.Be.C Computer akan memeriksakan datanya. sesudah memeriksakan datanya pendaftar akan mendapatkan hasil pemeriksaan, dan dari hasil pemeriksaan itulah pendaftar akan melakukan pembayaran ke bendahara atas sebuah laporan penerimaan dari administrasi pada Lembaga Pendidikan B.Be.C Computer. Pada gambar juga dapat dilihat bahwa pada transaksi tersebut sistem akan memberikan laporan penerimaan kepada terminator Pimpinannya.

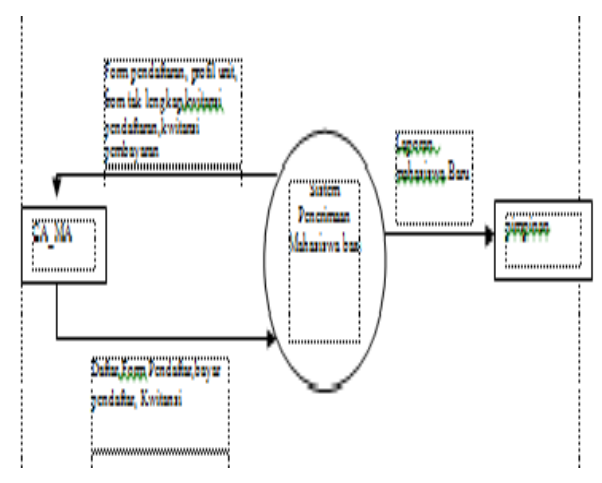

Gambar 4.1 centext Diagram (level 0)

\subsubsection{Diagram Zero (level 1) Sistem Informasi Penerimaan Mahasiswa Baru}

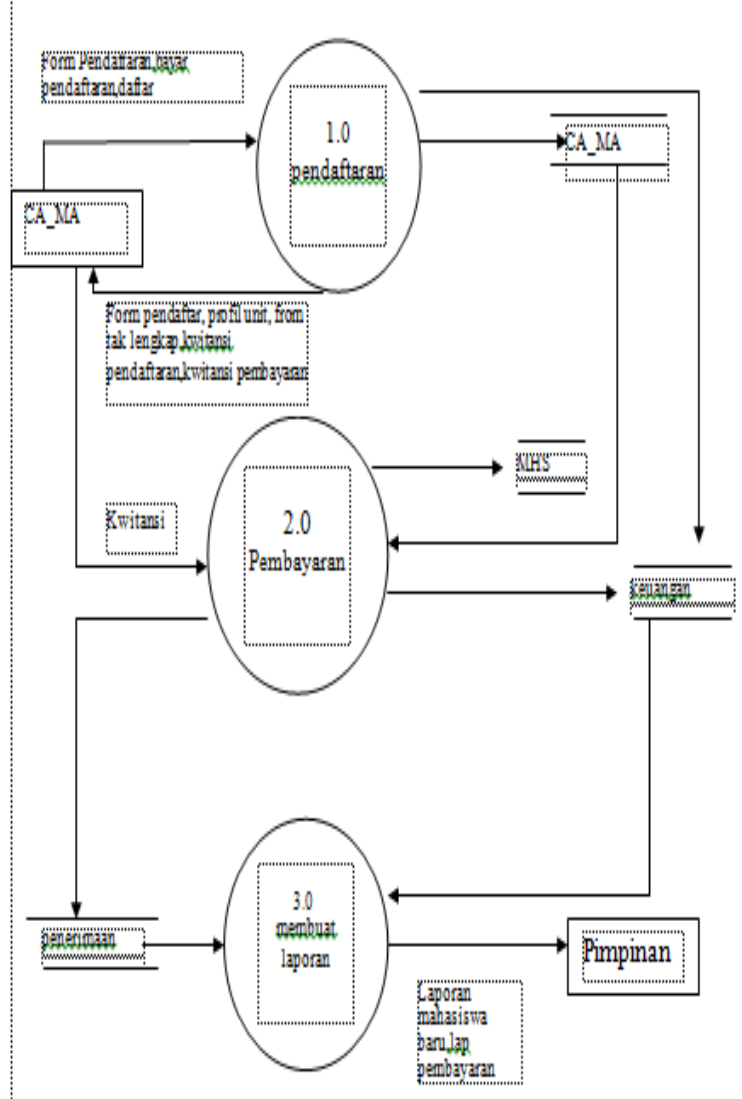

Gambar 4.2 Diagram Zero (level 1) Sistem Informasi Penerimaan Mahasiswa Baru

\subsubsection{Diagram Rinci (level 2) Proses 1.0 Penerimaan Mahasiswa Baru}

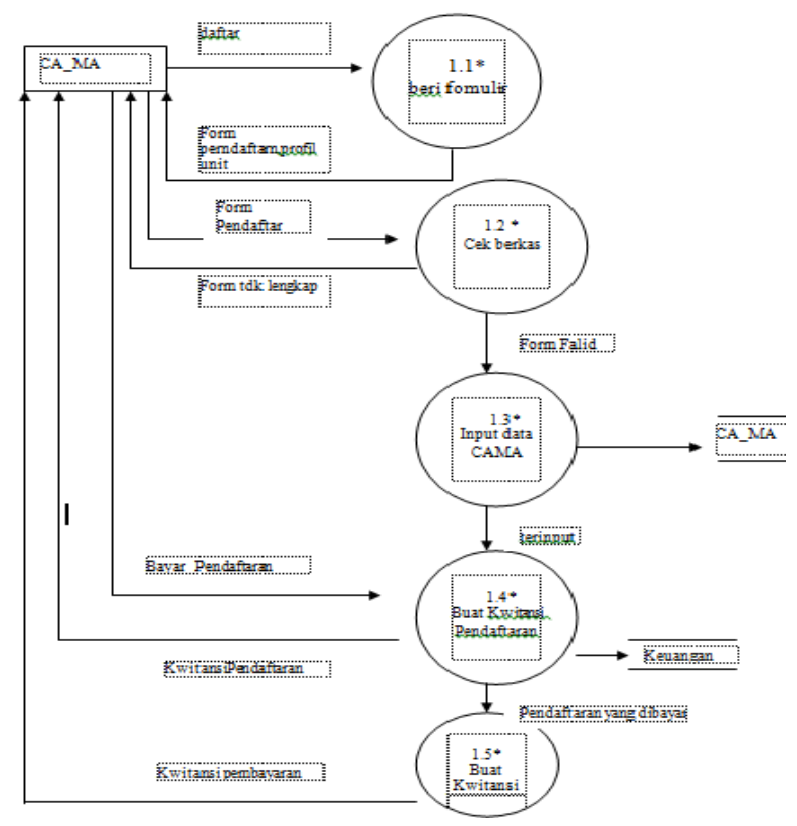


Gambar 4.3 Diagram Rinci (level 2) Proses 1.0

Penerimaan Mahasiswa Baru

\subsubsection{Diagram Rinci (level 2) Proses 2.0 Pembuatan Laporan Pembayaran}

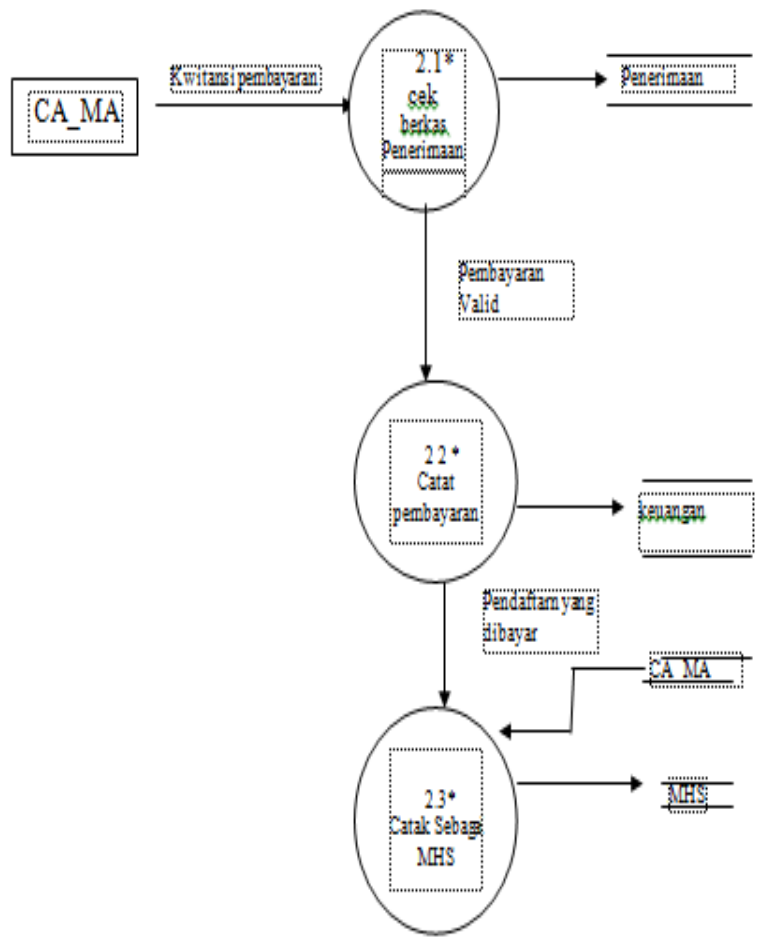

Gambar 4.4 Diagram Rinci (level 2) Proses 2.0 Pembuatan Laporan pembayaran

\subsubsection{Diagram Rinci (level 2) Proses 3.0}

\section{Pembuatan Laporan Pimpinan}

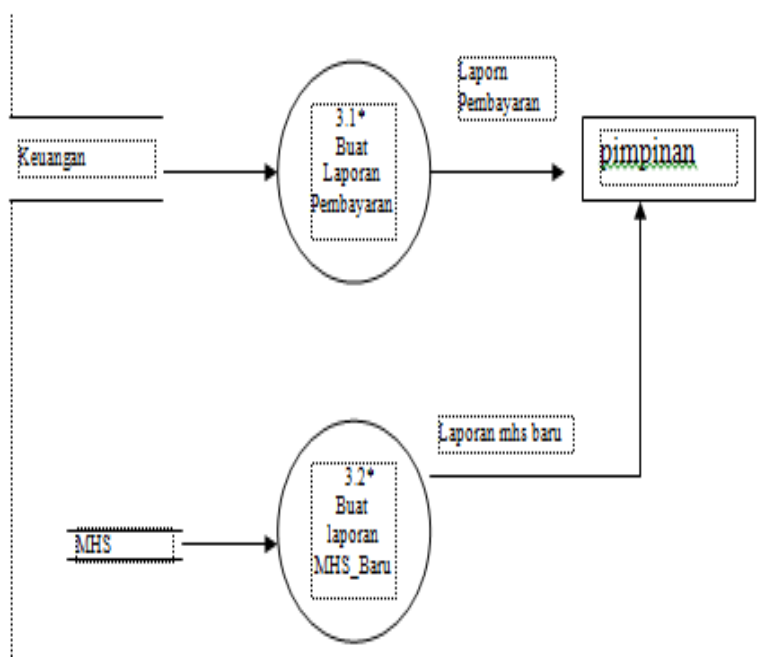

Gambar 4.5 Diagram Rinci (level 2) Proses 3.0 Pembuatan Laporan Pimpinan

4.2 ERD ( Entity Relation Diagram Sistem Informasi Penerimaan Mahasiswa `Baru

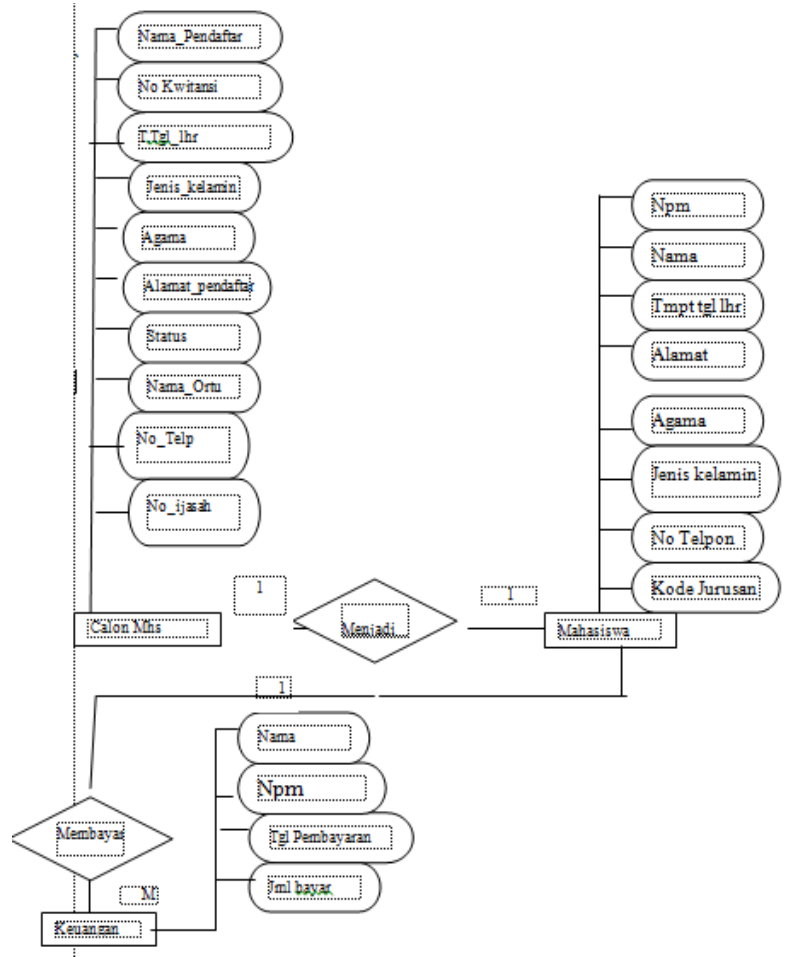

Gambar 4.6 ERD (Entity Relationship Diagram ) Sistem Informasi Penerimaan Mahasiswa Baru B.Be.C Computer Gedong Tataan Lampung Selatan

\section{SIMPULAN DAN SARAN 5.1 SIMPULAN}

Berdasarkan hasil dari pembahasan bab sebelumnnya, maka dapat disimpulkan sebagai berikut:

1. Lembaga Pendidikkan Widya Yahya B.Be.C Computer Gedong Tataan Lampung Selatan, dalam melakukan aktivitas kerja, terutama dalam proses Pembayaran masih dilakukan secara manual.

2. Lembaga Pendidikkan Widya Yahya B.Be.C Computer Gedong Tataan Lampung Selatan, dalam melakukan segala macam aktivitas kerja memerlukan waktu yang cukup lama, sehingga hasil yang diperoleh kurang tepat dan sangat tidak efisien.

3. Lembaga Pendidikkan Widya Yahya B.Be.C Computer Gedong Tataan Lampung Selatan, belum mengenal dan tidak memiliki sistem 
komputerisasi yang mampu menunjang aktivitas kerja, sehinga hasil yang didapat menjadi kurang efektif dan tidak efisien.

4. Lembaga Pendidikkan Widya Yahya B.Be.C Computer Gedong Tataan Lampung Selatan, memerlukan perubahansistem yang digunakan, yaitu dari sistem manual menjadi sistem komputerisasi.

\subsection{SARAN}

Saran - saran dari Peneliti untuk adalah sebagai berikut :

1. Lembaga Pendidikkan Widya Yahya B.Be.C Computer Gedong Tataan Lampung Selatan seiring dengan perkembangan jaman yang semakin terus berkembang dan maju, maka disarankan agar Lembaga Pendidikkan Widya Yahya B.Be.C Computer Gedong Tataan Lampung Selatan menggunakan sistem komputerisasi

2. Dengan adanya sistem informasi yang menggunakan sistem Komputerisasi, maka data - data untuk membuat laporan pembayaran dalam penerimaan mahasiswa akan semakin valid serta pengecekan data akan semakin akurat.

\section{DAFTAR PUSTAKA}

[1]Anonim, Nugroho Widjaanto, 1990, Dasar Konsep Sistem, Jakarta.

[2]Anonim, Robert $\mathrm{N}$ Anthon $\mathrm{Y}$ dan John Dearden, 1990, Konsep Dasar Informasi, Penerbit PT Pren Hallindo, Jakarta.

[3]Jogiyanto H M, 1990, Analisis dan Desain Sistem Informasi, Penerbit Andi, Yogyakarta.

[4]Jogiyanto H M, 1990, Pengenalan Komputer, Penerbit Andi, Yogyakarta.

[5]Panduan Praktis Pengoperasian Microsoft Visual FoxPro Secara Interaktif, 2000, Penerbit Wahana Komputer, Semarang dan Andi, Yogyakarta.

[6]7 Jam Belajar Visual Frox Pro 8.0 Untuk Orang Awam, 2004, Penerbit CV. Maxikom, Palembang. 